\title{
Penerapan Penjatuhan Sanksi Diversi Sebagai Alternatif Sanksi Pidana Penjara Untuk Anak Pelaku Tindak Pidana
}

\author{
Shinta Rukmi Budiastuti, Wibowo Murti Samadi \\ Fakultas Hukum \\ Universitas Slamet Riyadi \\ Shinta.rukmi.budiastuti@unisri.ac.id
}

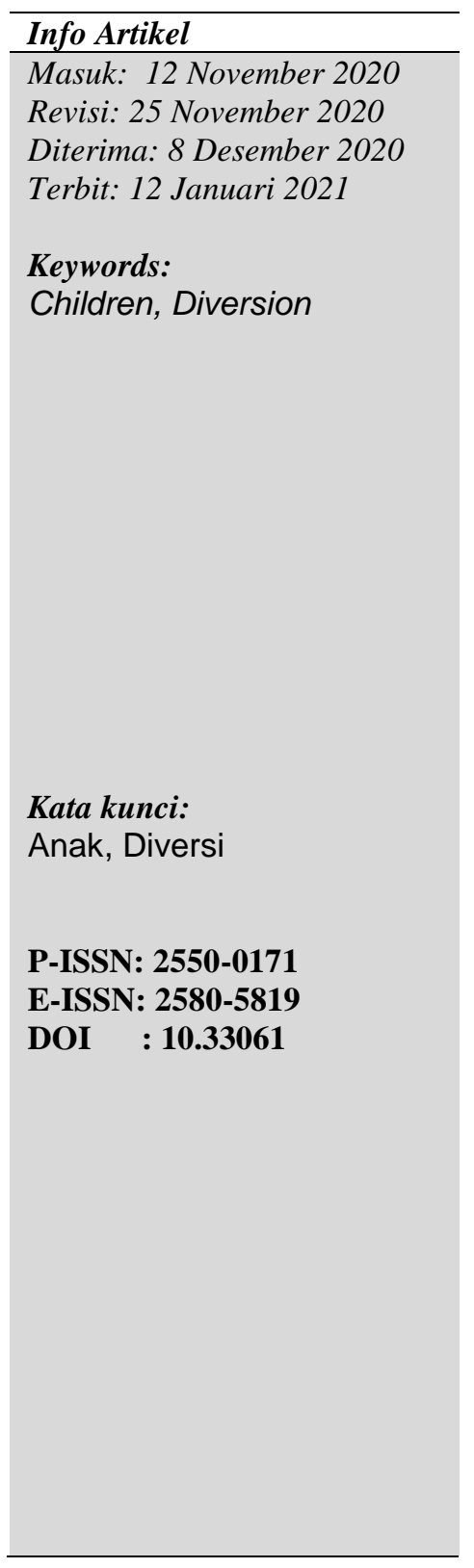

\begin{abstract}
The juvenile justice system for children in conflict with the law still takes into account the best interests of both the child without taking away the child's human rights and the child does not get negative stigmatization from the judicial process.

The purpose of this study is to identify and analyze law enforcement efforts to diversify and correct understanding is expected to be used as input for law enforcers who handle juvenile cases, so that diversion is an alternative to imprisonment.

This research was conducted to find legal principles in the concept of diversion and the concept of punishment, then used as a basis for assessing the requirements for diversion efforts and based on primary and secondary data.

Diversion is the best solution for children, as an alternative in imposing criminal sanctions. The Law on the Criminal Justice System for Children requires diversion for every child, it can only be done if the penalty is under 7 years old. Children who are subject to diversion sanctions create responsibility towards other people (victims, victims' families, schools) and are obliged to take risks for their actions.
\end{abstract}

\begin{tabular}{l}
\hline Abstrak \\
Sistem peradilan pidana anak yang diperuntukkan terhadap anak yang \\
berhadapan dengan hukum tetap memperhatikan kepentingan terbaik \\
baik anak tanpa merampas hak asasi anak dan anak tidak mendapatkan \\
stigmatisasi negatif dari adanya proses peradilan. \\
Tujuan penelitian ini yaitu untuk mengetahui dan menganalisa \\
penegakan hukum upaya diversi dan pemahaman yang tepat diharapkan \\
dapat dijadikan masukan kepada penegak hukum yang menangani \\
perkara anak, sehingga terwujud menggunakan dengan diversi sebagai \\
alternatif pidana penjara \\
Penelitian ini dilakukan untuk menemukan prinsip-prinsip hukum dalam \\
konsep diversi dan konsep pemidanaan,kemudian dijadikan landasan \\
untuk menilai persyaratan upaya diversi dan didasarkan data primer dan \\
sekunder. \\
Diversi menjadi solusi terbaik untuk anak, sebagai alternatif dalam \\
penjatuhan sanksi pidana.Undang-Undang Sistem Peradilan Pidana Anak \\
mensyaratkan diversi pada setiap anak, hanya dapat dilakukan apabila \\
ancaman pidananya di bawah 7 tahun. Anak yang dijatuhi sanksi diversi \\
menumbuhkan tanggungjawab terhadap orang lain (korban, keluarga \\
korban, sekolah) dan wajib mengambil resiko atas perbuatannya.
\end{tabular}




\section{PENDAHULUAN}

Seorang anak harus mendapat perlindungan dari cepatnya arus globalisasi di bidang komunikasi dan informasi sehingga sebagai penerus bangsa yang akan melanjutkan pembangunan yang memiliki tugas dan wewenang yang sangat penting serta memiliki karakter dan keistimewaan tertentu. Sebagai amanah Tuhan yang diberikan kepada setiap orang tua, maka sebagai orang tua harus memberikan pembelajaran yang sungguh-sungguh sedini mungkin.Ini karena anak memiliki hak atas kehidupan, kemerdekaan serta pengamanan dari siapapun tanpa terkecuali. Hal ini merupakan konsekuensi dari ketentuan Pasal 28B Undang-Undang Dasar Negara Republik Indonesia Tahun 1945 perlu ditindaklanjuti dengan membuat kebijakan pemerintah yang bertujuan melindungi Anak.

Setiap tahun anak yang menjadi pelaku tindak pidana selalu meningkat, dalam kasuskasus tertentu, anak yang menjadi pelaku menjadi perhatian khusus bagi aparat penegak hukum. Oleh karena itu, berbagai upaya pencegahan dan penanggulangan terhadap anak yang berhadapan dengan hukum, perlu segera dilakukan. Salah satu upaya pencegahan dan penanggulangan terhadap anak yang berhadapan dengan hukum saat ini melalui penyelenggaraan sistem peradilan pidana anak. Untuk melaksanakan pembinaan dan memberikan perlindungan terhadap anak, diperlukan dukungan, baik yang menyangkut kelembagaan maupun perangkat hukum yang lebih mantap dan memadai. Oleh karena itu ketentuan mengenai penyelengaraan pengadilan bagi anak perlu dilakukan secara khusus.

Indonesia adalah satu negara yang telah meratifikasi Konvensi Hak-Hak Anak (KHA) pada Tahun 1990 yang telah disetujui oleh Majelis Umum justice) melalui sistem diversi. PBB pada 20 November 1989. Konvensi Anak (Convention on the Rights of the Child) yang diratifikasi oleh pemerintah Indonesia melalui Keputusan Presiden Nomor 37 Tahun 1990, kemudian dituangkan dalam UndangUndang Nomor 4 Tahun 1979 tentang Kesejahteraan Anak, Undang-Undang Nomor 35 Tahun 20014 tentang Perlindungan Anak. Undang-Undang Nomor 11 Tahun 2012 tentang Sistem Peradilan Pidana Anak yang kesemuanya mengemukakan prinsip-prinsip umum perlindungan anak, yaitu non diskriminasi kepentingan terbaik bagi anak, kelangsungan hidup yang menghargai dan tumbuh berkembang. Hadirnya perangkat peraturan tersebut telah merumuskan perlindungan terhadap hak-hak anak

Melihat alasan ini maka diperlunya langkah-langkah strategis untuk melakukan perlindungan anak dari segi hukum. Sepanjang penggunaan sarana di luar sistem Peradilan pidana dipandang lebih efektif, maka proses peradilan pidana diupayakan untuk dihindarkan. Alasan dasarnya karena pengadilan akan memberikan stigmatisasi terhadap anak atas tindakan yang dilakukannya seperti anak dianggap jahat, sehingga lebih baik untuk menghindarkannya ke luar sistem peradilan pidana.

Upaya menghindari dampak negatif selama proses peradilan pidana anak yang diatur dalam United Nations Standard Minimum Rules For The Administration Of Juvenile Justice (The Beijing Rules) memberikan otoritas kewenangan aparat penegak hukum untuk mengambil tindakantindakan kebijaksanaan dalam menangani atau menyelesaikan masalah pelanggar anak dengan tidak mengambil jalan formal antara 
lain menghentikan atau tidak meneruskan dari proses peradilan atau mengembalikan dan menyerahkan kembali kepada masyarakat dan bentuk-bentuk kegiatan pelayanan sosial lainnya.

Penegakkan hukum pidana sebagai suatu proses harus dilihat secara realistis, sehingga penegakkan hukum secara aktual harus dilihat sebagai bagian diskresi yang tidak dapat dihindari karena berbagai keterbatasan. Penegakkan hukum pidana pada kenyataannya tidak dapat diharapkan sebagai satu-satunya sarana penanggulangan pidana yang efektif, mengingat kemungkinan besar adanya pelaku-pelaku tindak pidana yang berada di luar kerangka proses peradilan pidana. Penerapan hukum pidana sebagai sarana penanggulangan kejahatan yang dilakukan olah anak pada dasarnya bersifat dilematis. Di satu sisi, penggunaan hukum pidana sebagai sarana penanggulangan kejahatan yang dilakukan anak dengan menempatkan anak sebagai pelaku kejahatan menimbulkan dampak negatif yang sangat kompleks, tetapi disisi lain penggunaan hukum pidana sebagai sarana penanggulangan kejahatan anak justru dianggap sebagai pilihan yang rasional dan legal.

Diversi pada hakikatnya juga mempunyai tujuan agar ana terhindar dan dampak negatif penerapan pidana. Diversi juga mempunyai esensi tetap menjamin anak tumbuh dan berkembang baik secara fisik maupun mental. Ditinjau secara teoretis dari konsep tujuan pemidanaan, maka pengalihanproses dan proses yustisial menuju proses non yustisial terhadap anak. Secara umum tujuan pemidanaan pada hakikatnya terdiri dan upaya untuk melindungi masyarkat di satu sisi dan melindungi individu (pelaku) di sisi yang lain.

Relevansi pengalihan proses dan proses yustisial menuju proses non yustisial dalam pidana yang dilakukan oleh anak terdapat dua aspek pokok tujuan pemidanaan tersebut, yaitu aspek perlindungan masyarakat dan aspek perlindungan individu dapat dijelaskan sebagai berikut : Dengan pengalihan tersebut, maka anak akan terhindar dan penerapan hukum pidana yang dalam banyak teori telah didalilkan sebagai salah satu faktor kriminogen. Dampak negatif penerapan hukum pidana, termasuk kepada anak akan melahirkan stigmatisasi maupun dehumanisasi yang justru dapat menjadi faktor kriminogen. Dengan demikian, maka menghindarkan anak dan penerapan hukum pidana (depenalisasi) justru dapat menghindarkan adanya faktor kriminogen, berarti juga menghindarkan anak dan kemungkinan menjadi jahat kembali (residivis), oleh karenanya juga berarti menghindarkan masyarakat dan kemungkinan menjadi korban akibat kejahatan. Dengan Diversi/ pengalihan tersebut juga akan memberikan dua keuntungan sekaligus terhadap individu anak. Pertama, dengan pengalihan tersebut anak akan tetap dapat melakukan komunikasi dengan lingkungannya, sehingga dengan demikian anak tidak perlu lagi melakukan readaptasi sosial pasca terjadinya kejahatan. Kedua, dengan pengalihan itu juga anak akan terhindar dari kemungkinan dampak negatif prisonisasi yang seringkali merupakan sarana "transfer" kejahatan.

Pada kenyataannya diversi hanya dapat dilaksanakan dalam hal tindak pidana yang dilakukan itu diancam dengan pidana penjara di bawah 7 (Tujuh) tahun dan bukan merupakan pengulangan tindak pidana. Sehingga menjadi tidak konsisten, apabila tujuan diversi adalah menghindarkan anak dari proses peradilan, dan hasil 
kesepakatan diversi yang dianggap dapat memberikan konsekuensi terbaik bagi anak justru adanya pembatasan diversi terhadap anak yang mengulangi tindak pidana dan hanya khusus untuk anak yang diancam dengan pidana penjara paling tinggi 7 , sementara landasan awal terbentuknya konsep diversi adalah untuk mencari kepentingan terbaik anak. Meninjau hal ini maka diperlukannya pemahaman prinsip konsep diversi dan konsep pemidanaan sehingga sejalan dengan hak-hak anak sebagai tahap penetapan sanksi dalam hukum pidana anak. Penelitian ini memberikan wacana baru kepada aparat penegak hukum untuk menangani perkaraperkara anak dengan menggunakan upaya diversi.

\section{METODE PENELITIAN}

Penelitian hukum normatif adalah suatu proses untuk menemukan suatu aturan hukum, prinsip-prinsip hukum, maupun doktrindoktrin hukum untuk menjawab permasalahan hukum yang dihadapi. Penelitian ini dilakukan untuk menemukan prinsip-prinsip hukum dalam konsep diversi dan konsep pemidanaan. Penemuan prinsip hukum tersebut kemudian dijadikan landasan untuk menilai persyaratan upaya diversi pada anak yang berkonflik dengan hukum,yang didasarkan pada data primer dan sekunder. Data primer yaitu dengan menganalisis peraturan perundanganundangan yang sudah ada sedangkan data sekunder dilakukan dengan menganalisis bahan-bahan kepustakaan seperti buku, diktat, dan lain-lain yang dihubungkan dengan peraturan perundang-undangan dan konsep para ahli hukum sebagai basis penelitiannya

\section{PEMBAHASAN}

Penerapan penjatuhan sanksi diversi sebagai alternatif sanksi pidana penjara untuk anak pelaku tindak pidana

Anak sebagai pihak yang belum cukup matang untuk lebih jauh memikirkan akibat dari suatu tindakan yang dilakukannya. Menurut batas usia berdasarkan ketentuan yang berlaku, seorang anak yang melakukan tindak pidana tetap harus mempertanggungjawabkan perbuatannya, meskipun terdapat perbedaan dengan orang dewasa, proses penjatuhannya maupun akibat yang harus dihadapi jika terbukti melakukan tindak pidana. Secara teoritis, peradilan pidana anak secara umum harus diarahkan untuk mewujudkan hal yang terbaik bagi diri anak.

United Nations Standard Minimum Rules for Non-Custodial Measures atau dikenal dengan Tokyo Rules menggunakan istilah "non-custodial measures". Istilah ini merujuk pada keputusan dari otoritas yang berwenang dalam tahapan proses peradilan pidana, yang mensyaratkan seseorang yang diduga atau diputus melakukan tindak pidana untuk melaksanakan kewajiban tertentu yang tidak melibatkan pemenjaraan. Konsep hukuman non penjara ini diperluas untuk memberikan opsi-opsi 
yang memungkinkan untuk menduplikasi jaminan yang sifatnya tradisional untuk beberapa terpidana yang dijatuhi hukuman penjara

Tujuan Sistem Peradilan Pidana menurut The Beijing Rules yang tercantum dalam Rule 5.1. sebagai berikut: "bahwa sistem peradilan untuk Anak akan mengutamakan kesejahteraan Anak dan akan meyakinkan bahwa reaksi apapun untuk Anak yang melanggar hukum akan selalu sepadan dengan situasi-situai baik pada para pelanggar hukumnya maupun pelanggaran hukum." terlihat jelas bahwa yang menjadi tujuan utama dari Sistem Peradilan Pidana Anak adalah memajukan kesejahteraan Anak, yang mempunyai arti menghindari penggunaan sanksi pidana yang hanya bersifat menghukum, dan tujuan lainnya adalah, harus memperhatikan prinsip proposionalitas yang berarti mengekang penggunaan sanksi-sanksi, yang kebanyakan dinyatakan dalam batasan-batasan ganjaran yang setimpal dengan beratnya pelanggaran hukumnya, tetapi juga memperhatikan pada pertimbangan keadaan pribadinya

Secara umum, keberadaan pidana non penjara untuk anak tersebut disambut baik oleh penegak hukum. Jaksa maupun hakim telah menyadari bahwa pidana terhadap anak harus benar-benar dijadikan upaya terakhir. Mereka menyadari bahwa sebagian besar anak yang melakukan tindak pidana dipengaruhi oleh lingkungannya yang gagal memberikan pendidikan dengan layak. Berdasarkan berbagai putusan pengadilan dalam kasus dengan terdakwa anak, trend penjatuhan putusan pidana penjara masih lebih populer jika dibandingkan bentuk pidana yang lain. Pidana penjara menjadi pidana yang paling banyak dijatuhkan, disusul dengan pidana pelatihan kerja, kemudian pidana dengan syarat, serta pidana pembinaan dalam lembaga. maupun hakim sebenarnya lebih memilih untuk melaksanakan diversi dalam menyelesaikan kasus anak jika dimungkinkan, penempatan bentuk pidana non penjara pada kemungkinan terakhir masih menyebabkan anak harus melalui proses peradilan pidana yang tidak mudah.

Proses peradilan terhadap anak seringkali kehilangan makna esensinya, yaitu sebagai mekanisme yang harus berakhir dengan upaya untuk melindungi kepentingan terbaik bagi anak (the best interest of child). Peradilan pidana anak seringkali merupakan proses yang hanya berorientasi pada penegakan hukum secara formal dan tidak berorientasi pada kepentingan anak. 
Di dalam Teori Restoratif Justice, proses penyelesaian tindakan pelanggaran hukum yang terjadi dilakukan dengan membawa korban dan pelaku (tersangka) bersamasama duduk dalam satu pertemuan untuk bersama-sama berbicara. Dalam pertemuan tersebut mediator memberikan kesempatan pada pihak pelaku untuk memberikan gambaran yang sejelas-jelasnya mengenai tindakan yang telah dilakukannya. Keadilan restoratif adalah suatu proses dimana semua pihak yang terlibat dalam suatu tindak pidana tertentu bersama-sama memecahkan masalah bagaimana menangani akibat di masa yang akan datang.

Pengalihan penyelesaian perkara anak ke luar jalur formal peradilan melalui diversi yang diatur dalam instrumen internasional anak membawa implikasi yuridis bagi Indonesia untuk mengakomodir ketentuan diversi dalam peraturan perundangundangan anak di Indonesia. Undang-Undang Nomor 11 Tahun 2012 tentang Sistem Peradilan Pidana Anak yang berlaku efektif sejak tanggal 31 Juli 2014 bertujuan untuk menjaga harkat dan martabat anak dengan pendekatan restorative justice, seorang anak berhak mendapatkan perlindungan khusus, terutama pelindungan hukum dalam sistem peradilan pidana. Oleh karena itu, Sistem Peradilan Pidana Anak tidak hanya ditekankan pada penjatuhan sanksi pidana bagi anak pelaku tindak pidana, melainkan juga difokuskan pada pemikiran bahwa penjatuhan sanksi dimaksudkan sebagai sarana mewujudkan kesejahteraan anak pelaku tindak pidana tersebut. Hal demikian sejalan dengan tujuan penyelenggaraan Sistem Peradilan Pidana Anak yang dikehendaki oleh dunia internasional.

Undang-Undang Sistem Peradilan Pidana Anak memberi peneguhan terkait dengan perlindungan terhadap anak di Indonesia. Undang-undang inilah yang memperkenalkan konsep diversi yang bertujuan untuk memberikan perlindungan terhadap anak yang berkonflik dengan hukum, anak yang menjadi korban tindak pidana, dan masyarakat pada umumnya sebagai sebuah bentuk pengalihan penyelesaian perkara anak dari proses peradilan ke proses di luar peradilan pidana demi mewujudkan keadilan restoratif (restorative justice).

Pelaksanaan diversi dilatarbelakangi keinginan untuk menghindari efek negatif, khususnya terhadap jiwa dan perkembangan anak yang berpotensi terjadi apabila penyelesaian proses pidananya dilakukan melalui sistem peradilan pidana. Penerapan ketentuan diversi merupakan hal yang penting, karena dengan diversi, maka hakhak 
asasi anak dapat lebih terjamin, dan menghindarkan anak yang berkonflik dengan hukum dari stigma sebagai anak nakal, karena tindak pidana yang diduga melibatkan seorang anak sebagai pelaku dapat ditangani tanpa perlu melalui proses hukum.

Peradilan anak dengan menggunakan diversi dalam restorative justice berangkat dari asumsi bahwa tanggapan atau reaksi terhadap perilaku delinkuensi anak tidak efektif tanpa adanya kerjasama dan keterlibatan dari korban, pelaku, dan masyarakat. Prinsip yang menjadi dasar adalah keadilan paling baik terlayani, apabila setiap pihak menerima perhatian secara adil dan seimbang, aktif dilibatkan dalam proses peradilan dan memperoleh keuntungan secara memadai dari interaksi mereka dengan sistem peradilan anak

Konsep diversi sebagai instrumen dalam restorative justice berdasarkan UndangUndang Nomor 11 tahun 2012 tentang Sistem Peradilan Pidana Anak adalah pengalihan penyelesaian perkara anak yang berkonflik dengan hukum dari peroses peradilan pidana pidana ke peroses di luar peradilan dengan melibatkan pelaku, korban keluarga pelaku dan keluarga korban serta pihak lain yang terkait untuk bersama-sama mencari penyelesaian yang adil dengan menekankan pemulihan kembali pada keadaan semula dan bukan pembalasan. Diversi pada hakikatnya juga mempunyai tujuan agar anak terhindar dari efek negatif penerapan pidana. Diversi juga mempunyai esensi tetap menjamin anak tumbuh dan berkembang. Dengan demikian, maka juga dapat dikatakan bahwa pada dasarnya diversi mempunyai relevansi terhadap tujuan pemidanaan bagi anak. Secara umum tujuan pemidanaan terdiri dari upaya untuk melindungi masyarakat di satu sisi dan melindungi (pelaku) di sisi lain. Penyelesaian pidana melalui diversi itu bertujuan untuk menyadarkan kepada pelaku bahwa tindak pidana yang dilakukan itu tidak dapat dibenarkan dan telah merugikan pihak lain. Oleh karena itu, jika diversi berhasil disepakati para pihak-pihak yang terkait terutama pihak korban di tingkat penyidikan (Polres) maka anak (pelaku) akan segera memperoleh pemulihan hak-haknya. Sebaliknya jika belum berhasil diversi akan dilanjutkan di tingkat penyelidikan (Kejaksaan), dan jika tetap belum berhasil diversi akan diteruskan sampai di pengadilan. Pelaksanaan diversi di Kepolisian paling lama 30 (tiga puluh) hari (Pasal 29 Ayat (2) Undang-Undang Sistem Peradilan Pidana Anak), begitupun juga di Kejaksaan paling lama 30 (tiga puluh) hari (Pasal 42 Ayat (2) Undang-Undang Sistem Peradilan Pidana Anak), dari selanjutnya 
di Pengadilan paling lama 30 (tiga puluh) hari (Pasal 52 Ayat (3) Undang-Undang Sistem Peradilan Pidana Anak).

Penerapan diversi sebagai tujuan mewujudkan keadilan restoratif sudah tercantum dalam sistem peradilan pidana anak di Indonesia, pada hakikatnya sistem peradilan pidana anak harus ditujukan untuk melindungi hak-hak dan kepentingan anak. Atas dasar hal tersebut dapat dikatakan bahwa proses peradilan pidana anak untuk penjatuhan pidana adalah ultimum remedium dan bukan primum remedium, tujuan proses peradilan pidana anak bukanlah ditujukan pada penghukuman, melainkan perbaikan kondisi, pemeliharaan dan perlindungan anak serta pencegahan pengurangan tindakan pengadilan yang konstruktif.

Sistem peradilan pidana anak yang diperuntukkan terhadap anak yang berhadapan dengan hukum tetap memperhatikan kepentingan terbaik baik anak tanpa merampas hak asasi anak dan supaya anak tidak mendapatkan stigmatisasi negatif dari adanya proses peradilan. Sebenarnya proses pengadilan dibentuk oleh negara untuk menyelesaikan konflik yang muncul dalam masyarakat dan bersifat netral. Akan tetapi pengadilan bukanlah satu-satunya institusi dalam menyelesaikan konflik, karena pihak-pihak yang berkonflik tidak selamanya menggunakan mekanisme penyelesaian pada badan peradilan seperti penyelesaian anak yang berhadapan dengan hukum dengan jalur diluar pengadilan.

Perlindungan yang mengedepankan kesejahteraan demi kepentingan terbaik bagi Anak. Sesuai dengan asas dalam pembentukan Sistem Peradilan pidana Anak Pasal 2 UU SPPA yang menyangkut: perlindungan, keadilan, nondiskriminasi, kepentingan terbaik bagi Anak, penghargaan terhadap pendapat Anak, kelangsungan hidup dan tumbuh kembang Anak, pembinaan dan pembimbingan Anak, proposional, perampasan kemerdekaan dan pemidanaan sebagai upaya terakhir, dan penghindaran pembalasan.

Pelaksanaan divesi di Indonesia terlihat memang hanya melindung Anak yang melakukan tindak pidana dalam perbuatan tertentu hal ini terlihat dalam penjelasan Pasal 9 ayat (1) dijelaskan Diversi tidak dimaksudkan untuk dilaksanakan terhadap pelaku tindak pidana yang serius, misalnya pembunuhan, pemerkosaan, pengedar narkoba 13 dan terorisme, yang diancam pidana diatas 7 tahun. 
Diversi dapat dilakukan pada tahap penyidikan, penuntutan, dan tahap pemeriksaan pengadilan. Implementasi diversi ini disatu pihak melindungi anak, dimana pihak masyarakat atau korbanpun tetap terlindungi. Perlindungan terhadap korban pun tetap ada jika melihat syarat-syarat dan progam-progam diversi yang harus dilakukan pada anak. Namun demikian tujuan utama implementasi diversi adalah menghindari terhadap efek negatif proses peradilan pidana, dan digantikan dengan pembinaan di luar sistem peradilan pidana dengan mengikutsertakan masyarakat luas.

Pidana penjara diletakkan dalam porsi paling terakhir dalam UndangUndang Sistem Peradilan Pidana Anak, hal ini tercermin berdasarkan pengaturan Pasal 81 ayat(5), yang menyatakan bahwa pidana penjara terhadap Anak hanya digunakan sebagai upaya terakhir. Pidana pembatasan kebebasan diberlakukan dalam hal Anak melakukan tindak pidana berat atau tindak pidana yang disertai dengan kekerasan dan Anak dijatuhi pidana penjara di LPKA apabila keadaan dan perbuatan anak akan membahayakan masyarakat. Pidana penjara yang dapat dijatuhkan kepada Anak paling lama $1 / 2$ (satu perdua) dari maksimum ancaman pidana penjara bagi orang dewasa serta minimum khusus pidana penjara tidak berlaku terhadap anak.

Konsep diversi memuat tujuan pemidanaan secara khusus yakni untuk mencegah anak berbuat kembali tindak pidana ini ditandai dengan adanya syarat diversi yang salah satunya bukanlah tindak pidana pengulangan. Namun tidak memuat pencegahan tindak pidana secara umum karena diversi pada dasarnya untuk menjaga mental anak. Teori gabungan adalah kombinasi dari teori relatif. Teori gabungan (integratif) mendasarkan pidana pada asas pembalasan dan asas tertib pertahanan tata tertib masyarakat, dengan kata lain dua alasan itu menjadi dasar dari penjatuhan pidana. Pada dasarnya teori gabungan adalah gabungan teori absolut dan teori relatif. Gabungan kedua teori itu mengajarkan bahwa penjatuhan hukuman adalah untuk mempertahankan tata tertib hukum dalam masyarakat dan memperbaiki pribadi si penjahat

Anak harus memenuhi tanggungjawab individu, maksudnya siap menerima dan mempertanggungjawabkan secara individu kejahatan yang dilakukan tanpa mencaricari alasan, inilah mengapa diversi berperan penting dalam mempertemukan para pihak agar pelaku mau mengakui kesalahannya dengan harapan timbul rasa malu dan jera. Selanjutnya tanggungjawab dan kebebasan, diversi membuat anak bebas dari 
beban hukum, namun bebas yang diharapkan adalah bebas yang bertanggungjawab dan komitmen untuk tidak mengulangi lagi. Adanya sistem pidana anak adalah wujud tanggungjawab sosial anak terhadap korban, sehingga anak harus rela memenuhi semua sanksi yang diberikan, terutama yang berkaitan dengan pembentukan moral dan spiritualitasnya. Selain itu pelaku anak yang dijatuhi sanksi diversi harus mempunyai tanggungjawab terhadap orang lain (korban, keluarga korban, sekolah) dan siap mengambil resiko atas perbuatannya.

\section{KESIMPULAN}

Pemidanaan dalam konsep diversi haruslah menjadi solusi terbaik dan menimbulkan kemanfaatan terhadap anak, sebagai alternatif dalam penjatuhan sanksi pidana. Hal ini didukung dengan adanya Undang-Undang Sistem Peradilan Pidana Anak yang mewajibkan adanya upaya diversi pada setiap anak yang berkonflik dengan hukum, namun didalam peraturan pelaksanaanya diversi hanya dapat dilakukan ketika ancaman pidananya di bawah 7 tahun.

\section{DAFTAR PUSTAKA}

Abdussalam, 2007, Hukum Perlindungan Anak, Jakarta: Restu Agung

Ali, Zainuddin, 2009, Metode Penelitian Hukum, Jakarta : Sinar Grafika

Arief,Barda Nawawl, 1994, Kebijakan Legislatif dalam Penanggulangan Kejahatan dengan Pidana Penjara, Semarang: Badan Penerbit Universitas Diponegoro.

Arief, Barda Nawawi, 1999, Beberapa Aspek Kebijakan Penegakan dan Pengembangan Hukum Pidana Bandung: P.T Citra Aditya Bakti.

Djanggih,Hardianto, "Konsepsi Perlindungan Hukum Bagi Anak sebagai Korban Kejahatan Siber Melalui Pendekatan Penal dan Non Penal", Jurnal Mimbar Hukum, Vol.30, No.2, Juni 2018.

Edyanto,Novi, "Restorative Justice Untuk Menyelesaikan Kasus Anak yang Berhadapan dengan Hukum", Jurnal IImu Kepolisian, Vol.11, No.3, Desember 2017

Folk. Kenneht,Early Intervention, 2003, Diversion and Youth Conferencing, ANational Review of Current Approach to Diverting Juvenile from the Criminal Justice System. Canberra: Commonwealth of Australia. Government Attorney-general's Departement.

Gultom, Maidin, 2014, Perlindungan Hukum Terhadap Anak Dalam Sistem Peradilan 
Pidana Anak di Indonesia, Bandung : Refika Aditama.

Hapsari,Indira, 2016, Kebijakan Hukum Pidana dalam Upaya Penanggulangann indak Pidana Narkotika Pelaku Anak, Diponegoro Law Journal,Vol.5(3)

Pancar Chandra Purnama \& Johny Krisnan, "Pelaksanaan Diversi Ditingkat Pengadilan Berdasarkan Undang-Undang Nomor 11 Tahun 2012 Tentang Sistem Peradilan Pidana Anak", Jurnal Varia Justicia, Vol.12, No.1, Oktober 2016

Prasetyo, Aedhi, 2016, Diversi Tindak Pidana Narkotika Terhadap Anak,

Priyatno, Dwidja, 2012, Wajah Hukum Pidana Asas dan Perkembangan, Bekasi: Gramata Publishing.

Ratomi, Achmad, "Konsep Prosedur Pelaksanaan Diversi Pada Tahap Penyidikan Dalam Penyelesaian Tindak Pidana yang Dilakukan Oleh Anak", Jurnal Arena Hukum, Vol.6, No.3, Desember 2013,

Kaimuddin,Arfan, "Perlindungan Hukum Korban Tindak Pidana Pencurian Ringan Pada Proses Diversi Tingkat Penyidikan", Jurnal Arena Hukum, Vol. 8, No.2, Agustus 2015

Legislative Program Review \& Investigations Committee Connecticut, Pre-Trial Diversion \& AlternativeSanction, https : // www. cga.ct.gov /2004 /pridata /Studies /Alternative_Sanctions_Briefing.htm, 2014

Marzuki, 2008 ,Peter Mahmud. Penelitian Hukum. Jakarta: Kencana.

Marpaung,Leden, 2009. Asas-Teori-Praktek Hukum Pidana. Jakarta: Sinar Grafika.

Raharjo, Trisno, 2011, Mediasi Pidana dalam Sistem Peradilan Pidana Suatu Kajian Perbandingan dan Penerapannya di Indonesia, Yogyakarta: Mata Padi Pressindo.

Taufik Makarao, 2013, Mohammad, dkk, Hukum Perlindungan Anak dan Penghapusan Kekerasan dalam Rumah Tangga, Jakarta: Rineka Cipta.

Wahyudi,Setya, 2011, Implementasi Ide Diversi dalam PembaharuanSistem Peradilan Pidana Anak di Indonesia, Yogyakarta: Genta Publishing. 